\title{
護岸水衝部における三次元流れと 河床形状の観測法と解析法の開発 A NEW METHOD FOR MEASURING AND CALCULATING THREE-DIMENSIONAL FLOWS AND BED FORMS AROUND RIVER BANKS
}

\author{
輿石 大 1 - 内田龍彦 $2 \cdot$ 福岡捷二 3 \\ Masaru KOSHIISHI, Tatsuhiko UCHIDA and Shoji FUKUOKA \\ 1学生会員 中央大学大学院 理工学研究科 土木工学専攻（干112-8551 東京都文京区春日1-13-27） \\ 2正会員 博(工) 中央大学研究開発機構准教授（干112-8551 東京都文京区春日1-13-27） \\ 3 フェロー 工博 Ph.D 中央大学研究開発機構教授（干112-8551 東京都文京区春日1-13-27）
}

\begin{abstract}
Detailed profiles of three-dimensional flow structures and bed-forms using a new ADCP (Acoustic Doppler Current Profiler) method was developed for flow attacking on a revetment in the full scale experiment in the Jyoganji River. In the present method, individual beam data for current profiling is managed for velocity and bed profiles. This paper supplies detailed data of velocity distributions and bed forms by the field experiment. And, we proposed a numerical analysis method for the local threedimensional flow structure around the revetment using bottom velocity computation method based on a depth integrated model. We demonstrated the accuracy of the analytical method through the comparison with velocity distributions measured by the experiment. Furthermore, the results demonstrated that combined use of the new measuring and calculating method was reliable to understand three-dimensional flow structures in flow attacking zones with steep velocity gradients and local scouring around revetments.
\end{abstract}

Key Words : local flow, secondary flow, ADCP, revetment, field experiment, bottom velocity computation method

\section{1. 序論}

コンクリート護岸は河岸を直接防護する一方で，最大 洗堀深の増大や下流部に新たな水衝部を形成する等の問 題が報告されている1). 技術的に信頼できる洗掘対策工法 を確立するためには，構造物周辺の局所流場を明らかに するとともにそれを再現出来る解析法を構築することが 重要である.

近年の計算機の高速化と解析技術の発達により三次元解 析を用いて水制の設置角度や長さが周辺の流れに与える影 響の検討が可能となりつつある

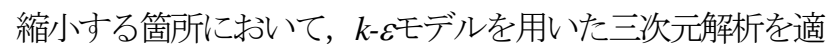
用し, 実験水路における低水護岸周辺の洗掘深や洗掘長さ を説明できることを示している. しかし，三次元解析の適 用は実験室等における小スケールの現象に留まっており， 実河川の洗掘問題に応用することは容易ではない．洪水時 における護岸等の水衝部の流れは，周辺の局所的な地形に 加えて，上下流の河道線形や水位縦断分布，流量八イドロ グラフ等により大きく変化し, 河床を構成する土砂の流れ もこれらに影響を受ける.このため, 洪水期間を通して広
い範囲の観測，解析とともに，対象地点における流れと河 床形状の詳細な観測, 解析が必要となる.

このような技術，学術の背景の中で，内田・福岡(4) は広 域の流れと河床変動解析に適用可能な平面二次元解析の 枠組みにおいて, 構造物周辺の局所的な三次元流れを再 現できる解析法(底面流速解析法)を検討している. 一方, 輿石ら ${ }^{5)}$ は解析法の検証データの取得と堤防際水衝部の三 次元流れ構造の実態把握のために，ADCPを応用した構 造物周辺の局所流場における三次元流速分布計測法を開 発し，2011年常願寺川現地実験に適用した。しかし，河 床高計測のためにADCPに搭載されているボトムトラッ ク (BT) のビームデータが多くの計測点において取得でき なかった等, 流れと河床形状の一体的な観測方法につい ては課題が残されていた. ADCPは異なる4つの方向へと 発射されるビームを用いて流速鉛直分布や河床高を計測 するため，流れや断面形が急変する河岸付近において計 測誤差が大きくなることが報告されている(6),7). また， BT モードの使用には多くのパラメーターが用意されている が8), 現状では精度良く河床高を計測できるようにこれら を予め定めることは難しい. 


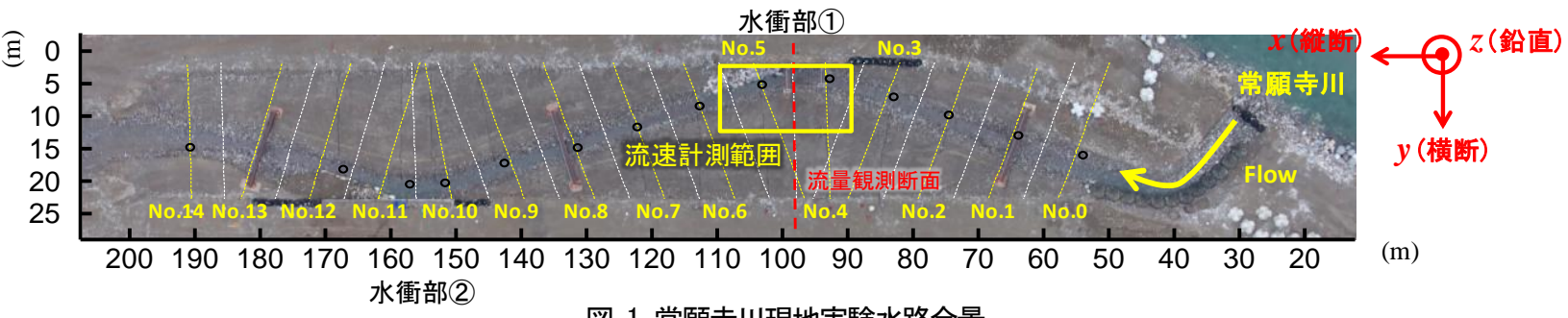

図-1 常願寺川現地実験水路全景

本研究では，流速計測に用いられるADCPのビーム データを用いた三次元流れと河床形状の高精度計測法を 開発する。 また，浅水流場の仮定を用いない底面流速解 析法を2011年常願寺川現地実験へ適用し，堤防護岸際局 所流場への適用性を検証することを目的としている.

\section{ADCPを用いた流れと河床形状の観測法}

本章では，流れと河床形状の一体的な観測法を行うた めに，著者らが提案してきたADCPを用いた三次元流れ の計測法 ${ }^{5}$ に加え，個別の流速ビームデータを用いる河床 形状の計測法を開発し，2011年常願寺川現地実験結果よ り精度を検証する．2011年常願寺川現地実験は堤防護岸 際の浸食・洗掘機構の解明と洗掘解析法の検討を目的と して行われた ${ }^{9)}$. 図-1に水路全景図，表-1に実験条件を示 す. 水路は複断面蛇行水路であり，コンクリート製の垂 直護岸 (図-2参照, 以下護岸)を上流の水衝部(1), 下流の 水衝部(2)に設けた。図-2に水衝部(1)の流速計測風景を示 す. 図-1内の黄枠線で示す流速計測範囲において，可動 式のレールを設置し，RD Instruments社製Workhorse ADCP Rio Grandeを固定したやぐらを左岸から牽引し，横断方向 に約 $0.1 \mathrm{~m}$ 毎に，サンプリング時間10.0sで計測した5)。また， 本実験は最大流速 $2.5 \mathrm{~m} / \mathrm{s}$ 程度と流速が大きく激しい流れで あり，ADCPの吃水をやや大きくしたため，送受信面の 水深と合わせて, 水面から $0.4 \mathrm{~m}$ 程度の区間が計測不能で あった．本実験ではこれを補完するため，二つの断面に おいて電磁流速計を用いて水面から $0.15 \mathrm{~m}$ 付近の計測も 行っている. ADCPを水没させることで生じる水面付近

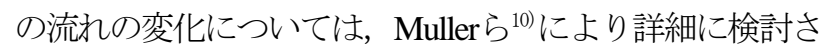
れており，平均流速 $2.0 \mathrm{~m} / \mathrm{s}$ の実験ではADCPの送受信面か ら0.2mにおいて約 $5 \%$ 程度流速が低下することが示されて いる．本実験ではADCPの送受信面から最も近い計測点 は0.22mであり，影響は小さいと考えられる.

\section{(1) 三次元流速分布計測法 ${ }^{5)}$}

図-3にADCP従来計測法の枠組みを示す(ここではy-z平面 のみ示すが， $x$-z平面においても同様である)，従来のADCP 流速計測では，測定箇所の流速值 $v\left(v_{x}, v_{y}, v_{z}\right)$ は, $\theta=20^{\circ}$ で発 射される各ビームにより，幅Lだけ離れた位置で計測さる ビーム方向流速值 $v_{I} \sim v_{4}$ を用いて, 式(1)から計算される ${ }^{8)}$.

$$
v_{x}=\frac{-v_{3}+v_{4}}{2 \sin \theta}, \quad v_{y}=\frac{-v_{1}+v_{2}}{2 \sin \theta}, \quad v_{z}=\left(\frac{v_{1}+v_{2}}{2 \cos \theta}+\frac{v_{3}+v_{4}}{2 \cos \theta}\right) / 2
$$

表-1 実験条件

\begin{tabular}{|c|c|c|c|c|c|}
\hline & $\begin{array}{c}\text { 断面平均 } \\
\text { 流速 } \\
{[\mathrm{m} / \mathrm{s}]}\end{array}$ & $\begin{array}{c}\text { 水面幅 } \\
{[\mathrm{m}]}\end{array}$ & $\begin{array}{c}\text { 平均水深 } \\
{[\mathrm{m}]}\end{array}$ & フルード数 & $\begin{array}{c}\text { 流量 } \\
{\left[\mathrm{m}^{3} / \mathrm{s}\right]}\end{array}$ \\
\hline 低水路 & 1.4 & 5.0 & 0.7 & 0.53 & 5.2 \\
\hline 高水敷 & 0.8 & 15.0 & 0.2 & 0.57 & 2.4 \\
\hline 全断面 & 1.1 & 20.0 & 0.3 & 0.64 & 7.6 \\
\hline
\end{tabular}

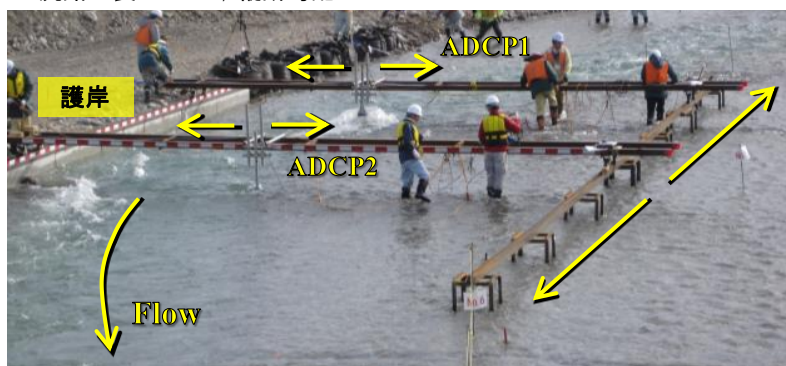

図-2 水衝部(1流速計測風景
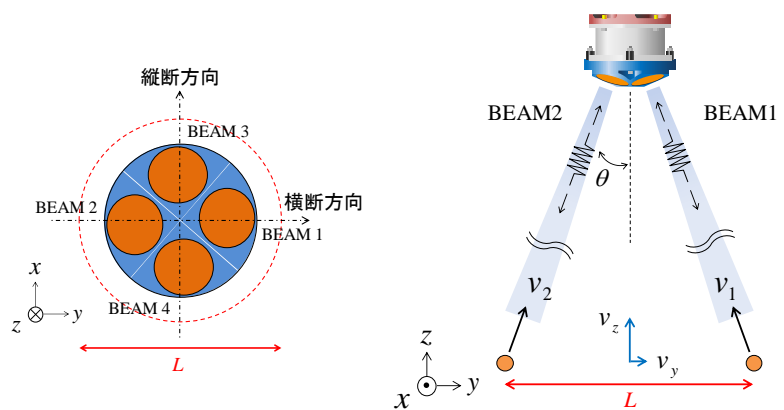

図-3 ADCP従来計測法の枠組み

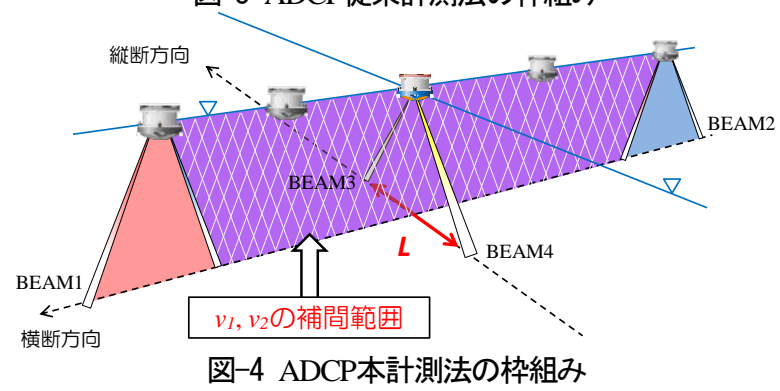

ここで, 幅 $L$ は水深に比例し， $1.0 \mathrm{~m}$ 毎に約 $0.7 \mathrm{~m}$ の広がり を持つため $\left(\theta=20^{\circ}\right)$, 局所的に流速が大きく変化する 箇所や水深の深い箇所では誤差が大きくなる. そこで, 本計測法では，図-4に示すように横断方向に連続的に計 測されたビーム方向流速值 $v_{1}, v_{2}$ を個別に取得する．観測 期間において流れが定常であるとし，計測領域内におい てそれぞれ空間的に補完した $v_{1 i n}, v_{2 i n}$ を再び重ね合わせ， 任意の点の流速 $v\left(v_{y}, v_{z}\right)$ を式(2)より計算する.

$$
v_{y}=\frac{-v_{1 i n}+v_{2 i n}}{2 \sin \theta}, \quad v_{z}=\frac{v_{1 i n}+v_{2 i n}}{2 \cos \theta}
$$

また，縦断方向流速 $v_{x}$ にいては，横断方向・鉛直方向 に比べ変化が小さいことから，従来の方法を用いて式(1), 
第一式で計算する．このように，独立した4本のビーム を個別に取得し，時空間的に平均，補間し重ね合わせる ことで，水衝部の流れを精度よく計測出来，特に，河床 付近において，4本のビームを平均する計測法と比較し て精度が向上することが明らかとなっている5).

\section{(2) ADCPの流速計測ビームを用いる河床形状計測法}

ADCPは流速計測用のビームの他に，河床形状計測用 のBTビームを有し，曳航観測ではBTビームから計測され たADCPの対地速度を利用し, 流速計測值を補正する ${ }^{6) \sim 8)}$. 流速計測には詳細な鉛直分布を計測するために短いパル スを用いているが，ADCPから発射される超音波は河床 面に対して角度を有し，有限の幅を持つため，短いパル スでは初めに前縁が，最後に後縁が河床から異なる時刻 に反射する．これは，超音波の両端においてドップラー シフトが異なる原因となるため，BTビームでは長いパル スを発射し対地速度を精度よく計測する。しかし， BT モードの使用には, Intensity (振幅 : $\mathrm{dB}$ ), Correlation(相 関 : count) 值等の閾值を適切に設定する必要があり ${ }^{8)}$, 河 床や水深，水質の条件によって変化するため, 河床高の 計測に誤差を含むことが報告されている6),8)．また，河床 表層の砶径の大きい本実験では，パラメーターに初期設 定值を使用した結果，多くの地点でデータが取得できな かった．これらの閾值を予め設計することは困難である ため, 本計測法では流速計測用のビームにより計測され る各パラメーターの鉛直分布を用いて，後処理により河 床高を計測する方法を検討する. 図-5，6に横断的に計測 したCorrelation值, Intensity值のBEAM1 計測結果をコン ターで示す。同図にはトータルステーション(TS)により 計測された河床形状を青の実線で示している. Intensity值 に比べてCorrelation值は河床高さ付近において明確な変化 を示していることが分かる．また，Intensity值は計測箇所 や，計測断面によりばらつきが大きかった。このため本 計測法では, Correlation值の分布から河床形状を推定する. 図-7にCorrelation值が210countの地点を河床面と定義した 時のBEAM1，BEAM2における河床形状の推定值とTS河 床形状計測值を示す．本実験では計測の測定層厚を $0.05 \mathrm{~m}$ としたこと, 河床表層の最大粒径が $0.1 \mathrm{~m}$ 程度であること から, 本計測法と実測では最大で $0.1 \mathrm{~m}$ 程度の誤差が生じ ているが，実用上十分な精度で河床形状を推定できる.

以上より，本観測法は流速鉛直分布と河床形状を精度 良く計測可能なため, 構造物周辺の洗掘問題に対して有 効なデータを取得できる.

\section{3. 浅水流場の仮定を用いない底面流速解析法}

図-8に底面流速解析法の枠組みを示寸，底面流速解析 法では, 河床 $z_{0}$ からわずかに上の面 $z_{b}\left(z_{b}=z_{0}+\delta_{z_{b}}, \delta_{z_{b}} / h<<1\right)$ を底面とし，底面から水面までの流れが解かれる。底面 流速は水深積分渦度と水表面流速，水深積分鉛直方向流

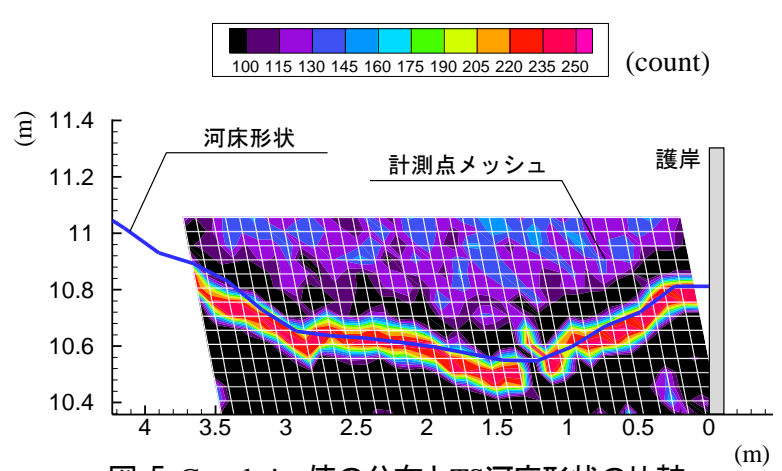

図-5 Correlation値の分布とTS河床形状の比較 (m)

$\begin{array}{lllllllll}222.5 & 222.75 & 223 & 223.25 & 223.5 & 223.75 & 224 & 224.25 & 224.5\end{array}$ (dB)

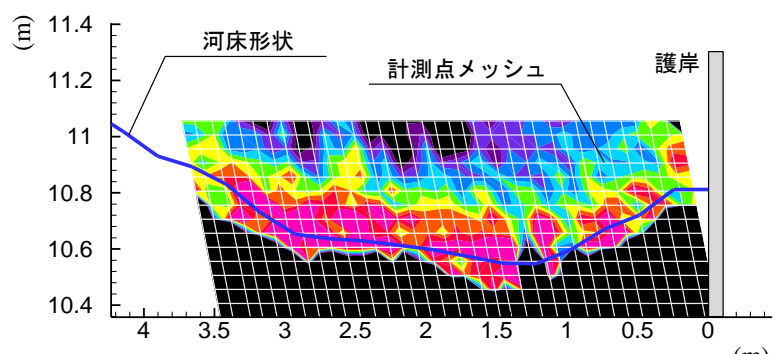

図-6 Intensity值の分布とTS河床形状の比較

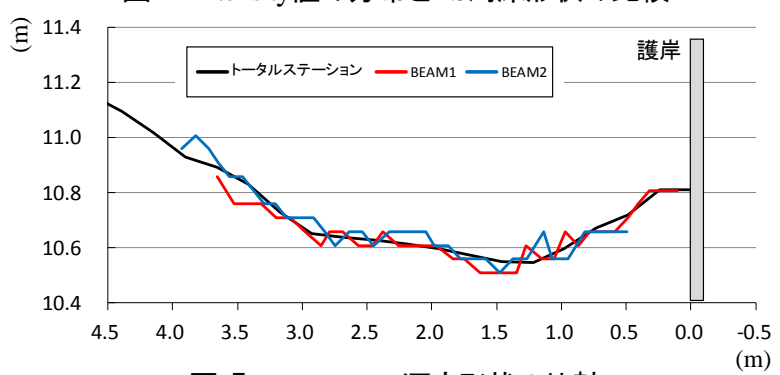

図-7 ADCP, TS河床形状の比較

速を用いて式(3)で表す，なお，底面の位置は底面せん断 応力と底面流速の関係式によって定義されることとなる。

$$
u_{b i}=u_{s i}-\varepsilon_{i j 3} \Omega_{j} h-\left(\frac{\partial W h}{\partial x_{i}}-w_{s} \frac{\partial z_{s}}{\partial x_{i}}+w_{b} \frac{\partial z_{b}}{\partial x_{i}}\right)
$$

ここに, $i, j=1,2(x, y$ 方向 $), u_{s i}: i$ 方向水表面流速, $u_{b i}: i$ 方 向底面流速, $\varepsilon_{i j 3}$ : エディトンのイプシロン, $\Omega_{j}$ : 水深平 均 $\mathrm{j}$ 方向渦度, $h:$ 水深, $W$ : 水深平均鉛直方向流速, $z_{s}$ : 水位, $z_{b}$ : 河床高, $w_{s}, w_{b}$ : 水面, 底面の鉛直方向 流速である．流速鉛直分布は式(4)の三次多項式を用いる.

$$
u_{i}^{\prime}=u_{i}-U_{i}=\Delta u_{i}\left(12 \eta^{3}-12 \eta^{2}+1\right)-\delta u_{i}\left(4 \eta^{3}-3 \eta^{2}\right)
$$

ここに, $u_{i}: i$ 方向流速, $U_{i}: i$ 方向水深平均流速, $\Delta u_{i}=u_{s i}$ $-U_{i}, \quad \delta u_{i}=u_{s i}-u_{b i}, \quad \eta=\left(z_{s}-z\right) / h, z:$ 基準面からの高さ(鉛直 上向きを正)である．ここで，対象とする流れ場の鉛直方 向スケールが水平方向スケールに比べ十分小さいならば, 式(3)の括弧付きの項を省略することができる（浅水流場 の仮定 ${ }^{4)}$ と呼ぶ）。輿石ら ${ }^{11}$ は，合流部の実測デー夕に対 し, 浅水流場の仮定を用いた底面流速解析法を適用し, 合流部の主流と二次流の分布やそれに伴う水深平均流れ 場の特徵を概ね説明出来ることを明らかにした. しかし， 本研究で対象とする堤防護岸際の水衝部では, 後述する 


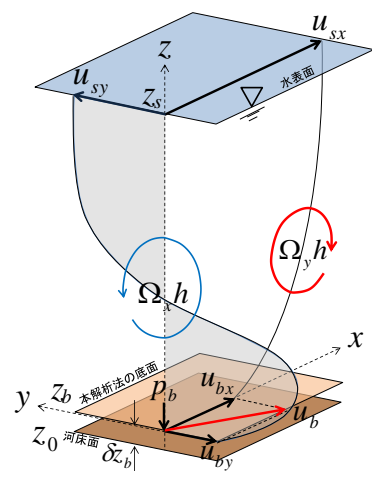

図-8 底面流速解析法の枠組

ように護岸前面で大きな下降流が生じ，水平方向スケー ルと鉛直方向スケールが同程度であり，括弧付きの水深 積分鈆直方向流速に関する項を無視することができない こと, 圧力分布が静水圧分布から大きく外れ, 流れの解 析においてはこれを考慮することが必要となることから， 本研究では, 式(3)により底面流速を求めるため, 連続式, 水深積分運動方程式に加えて, 水深積分渦度方程式(5) と 水表面流速方程式(6), 水深積分鉛直方向流速式(8)を解く

$$
\begin{aligned}
\frac{\partial \Omega_{i} h}{\partial t}= & E R_{\sigma i}+P_{\omega i}+\frac{\partial h D_{\omega i j}}{\partial x_{j}} \\
E R_{\sigma i} & =u_{s i} \omega_{s \sigma}-u_{b i} \omega_{b \sigma} \\
D_{\omega i j} & =-U_{j} \Omega_{i}+U_{i} \Omega_{j}+\overline{\omega^{\prime}{ }_{j}^{\prime} u_{i}^{\prime}}-\overline{\omega_{i}^{\prime} u_{j}^{\prime}} \\
& +\frac{v_{t}}{\sigma_{\omega}} \frac{\partial \Omega_{i}}{\partial x_{j}} \\
\overline{\omega_{i}^{\prime} u_{j}^{\prime}} & =-\Omega_{i}\left(\frac{\delta u_{j}}{10}+\frac{\Delta u_{j}}{5}\right)
\end{aligned}
$$

ここに, $E R_{\sigma i}$ は水面と底面に垂直な渦の回転， $D_{\omega i j}$ は水 平方向の移流，回転・伸縮，分散，乱流混合による渦度 のフラックスである. $\omega_{s \sigma}, \omega_{b \sigma}$ はそれぞれ $u_{s i}, u_{b i}$ の回転で 評価する．なお，式(5)の上付きバーで示している箇所は， 渦度と流速の鉛直分布による二次の相関項であり，仮定 した流速鉛直分布を用いて水深積分することで求めてい る．渦度の鉛直分布は式(4)の一階微分としている．また， 水深積分運動方程式の応力項においても同様に評価し, 流速鉛直分布による水平方向の運動量輸送を考慮してい る. 水表面流速方程式は, 水面での運動学的境界条件, 力学的境界条件を与えることにより式(6)で表わされる.

$$
\frac{\partial u_{s i}}{\partial t}+u_{s j} \frac{\partial u_{s i}}{\partial x_{j}}=-\left(g-d p_{z s}\right) \frac{\partial z_{s}}{\partial x_{i}}+P_{s i}
$$

ここに, $d p$ : 静水圧分布の偏差成分であり, $d p_{z s}$ : 水面 における $d p$ の鉛直勾配である. 生産項 $P_{s i}$ は，水面近傍に おいて無限小の層底面に働くせん断応力であり三次の流 速鈆直分布式(4)を用いて式(7)で与えられる.

$$
P_{s i}=\frac{2 v_{t}}{h^{2}}\left\{12\left(u_{s e i}-u_{s i}\right)-\left(3 \delta u_{i}-6 \Delta u_{i}\right)\right\}
$$

鉛直方向流速の積分值の時間変化量は式(8)から計算され る.

$$
k_{1} \frac{\partial}{\partial x_{j}}\left(h^{2} \frac{\partial \phi}{\partial x_{j}}\right)+\phi^{P}-\phi=0
$$

ここに, $k_{1}$ : 係数 $(=1 / 20), \quad \phi=(W h)^{n+1}-(W h)^{n}, \quad \phi^{P}=(W h)^{P}-$ $(W h)^{n},(W h)^{n}: \delta u_{i}^{p}$ を用いた流速鉛直分布から計算され るWh， $\delta u_{i}^{p}:(W h)^{n}$ を用いて式(3)から計算される $\delta u_{i}$, $n$ : 時間ステップである. 底面圧力に関する方程式は水 深積分した鉛直方向運動方程式の非定常項とせん断応力 に関する項を省略した式(9)から得られる.

$$
\frac{\partial h W U_{j}}{\partial x_{j}}=\frac{d p_{b}}{\rho}-\tau_{b j} \frac{\partial z_{b}}{\partial x_{j}}
$$

本解析法では，圧力の非静水圧分布成分を直線分布で近 似し，底面圧力と水深平均值が運動方程式に，水面にお ける鉛直方向微分值を水表面流速方程式(6)に与える. ま た，これらの方程式は流速と圧力の鉛直分布を介して， 生産項や分散項により相互に影響しながら一体的に解か れる. 解析法の詳細は文献をを参照されたい.

\section{4. 常願寺川現地実験への適用}

\section{(1) 解析条件}

浅水流場の仮定を用いない底面流速解析法を常願寺川 現地実験に適用し, 解析法の妥当性を検証する. 解析の 境界条件には，流量よりも精度が高いと考えられる水位 を上下流に与える ${ }^{12)}$. 低水路と高水敷の粗度分布は河床 表層に存在する礫径の範囲内で, 実測の水位縦断分布や 流量, 流速分布を説明するように, $k s=0.2 \mathrm{~m}$ （縦断距 離: $0 \sim 80 \mathrm{~m}$ )， $0.1 \mathrm{~m}$ (緃断距離: $80 \sim 120 \mathrm{~m}$ )， $0.25 \mathrm{~m}$ (維断 距離：120〜200m)を用いている. 解析地形は縦断幅 $0.5 \mathrm{~m}$, 横断幅0.25mのデカルト座標メッシュに, $5.0 \mathrm{~m}$ 毎のTS測 量結果に加えて, 水衝部(1)ではADCP本観測法を用い, 詳細間隔で測られた河床形状の測定結果を利用する.

\section{(2) 実測と解析の比較}

図-9に実測と解析の縦断水面形の比較を，図-10に図11中の断面eにおける水深平均, 水表面流速の縦断方向 成分, 左右岸水位の比較を示寸．解析水位は $120 \mathrm{~m} よ り$ 下流において実測を若干下回っているものの, 水衝部1 付近においては, 左右岸の水位差を概祆説明出来ている

（図-9，図-10）。ただし，赤のプロットと実線で示す 低水路水面形において，82m〜110mの間で0.05m程解析 值が高くなっている.この理由について以下に考察する. 実測の水位は低水路と高水敷の境界付近において圧力式 水位計により計測された。 この付近は, 図-11に示寸様 に高水敷の流れが低水路に流入し，低水路と高水敷の間 で複雑な運動量の交換が生じる箇所であり, 図-10の解 析水位, 水深平均流速の横断分布に示寸様に, 流速分布 が局所的に変化するため, 横断方向に大きな水面勾配を 有する. 解析では, 水深平均流速, 水表面流速の分布を 


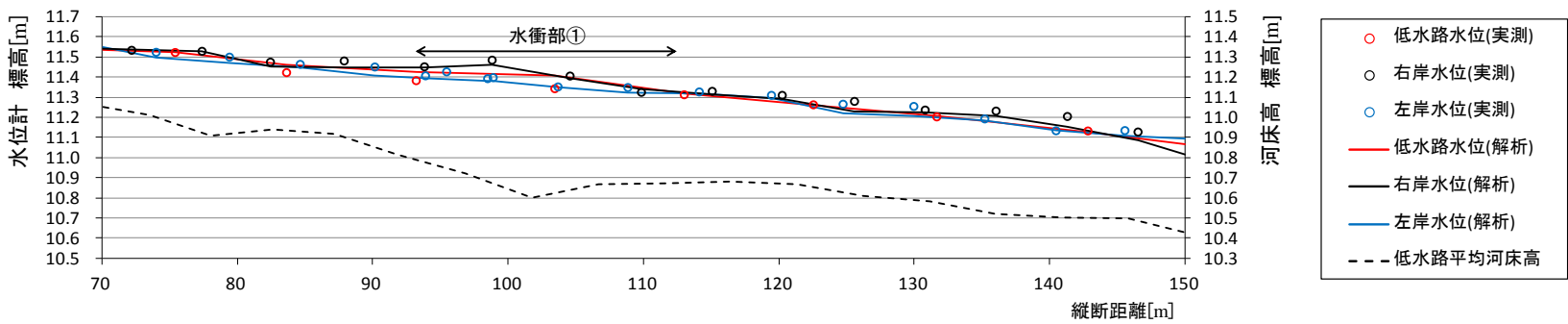

図-9 縦断水面形の比較

概ね説明出来ているものの, 後述するように主流線が十 分に右岸の護岸付近まで寄っていない。このため，低水 路と高水敷の境界付近において水位が低下寸る箇所が実 現象と異なり，低水路の縦断水面形（図-9，赤）に誤差 が生じたものと考えられる。しかし，本解析では低水路 内岸と外岸の水位差は $0.05 \mathrm{~m}$ 程度（図-10,0 $0 \mathrm{~m} \sim 5 \mathrm{~m}$ ）であ り，実測の水位差も同程度であること（図- $9,82 \mathrm{~m} \sim$ $110 \mathrm{~m} ）$ から，解析の水面形は概水実測の傾向を再現して いると考える. 図-11に底面流速ベクトルを黒実線の矢印, 水表面流速ベクトルを赤実線の矢印で示寸．実測值の底 面流速は水深の $70 \%$ の深さの流速とし，水表面流速は水 面から $0.15 \mathrm{~m}$ の高さの電磁流速計の計測值をそれぞれ示し ている. 解析值は本解析法により解か子る水表面, 底面 流速である. 図-12に断面c,e,fにおける流速鉛直分布をコ ンターで主流 $\left(v_{x}\right)$, ベクトルで二次流 $\left(v_{y}, v_{y}\right)$ を示寸. 断面 $\mathrm{c}, \mathrm{e}$ では電磁流速計の計測值から水面付近の主流速コン ターを合わせて示している. 実測では，断面c〜 f付近に おいて, 右岸の護岸付近で生じる下降流に伴う二次流が 発達している様子が分かる（図-11, 図-12）。また, 二 次流により主流速の運動量が低水路内岸の水面付近から 右岸一運ばれ，断面fでは底面付近においても高流速域が 発生している（図-12，断面f）。解析結果は二次流が実 測に比べさく, 断面にたおける底面付近の速い主流速も 再現出来ていない. この点について以下に考察する. 本 実験は図-12，断面c,eから分かる様に，主流速が水面付近 で急激に大きくなっている．この接近流速の主流がもつ 非常に大きな横断方向渦度が, 護岸に衝突し流れが变わ ることによって, 流下方向渦度へ変換され, 強い二次流 とそれによる外岸方向への運動量輸送を生じる複雑な流 れ場となる．解析では，図-10～12から分かるように，主 流速の鉛直分布における水面付近の局所的な変化を説明 出来ていないため, 接近流速の持つ渦度が小さく, 二次 流や運動量の輸送が過小評価されている。この理由は, 低水路や高水敷の河床抵抗分布や断面No.0（図-1）上流 の流入部における河床形状や粗度の評価が不十分である ことが考えられ, 今後の課題である. しかし, 複雑な水 路形状を有する本実験において, 本解析法は二次流と運 動量輸送の特性を概ね再現出来ていると考える. 特に, 流下方向に時計回りの二次流が生じる断面e,fにおいて, 実測では3〜 4m付近において下降流が発生しているが, 解析では絶対值が小さいものの，この点を再現出来てい る.この下降流の発生原因は, 解析結果から, 左岸の高

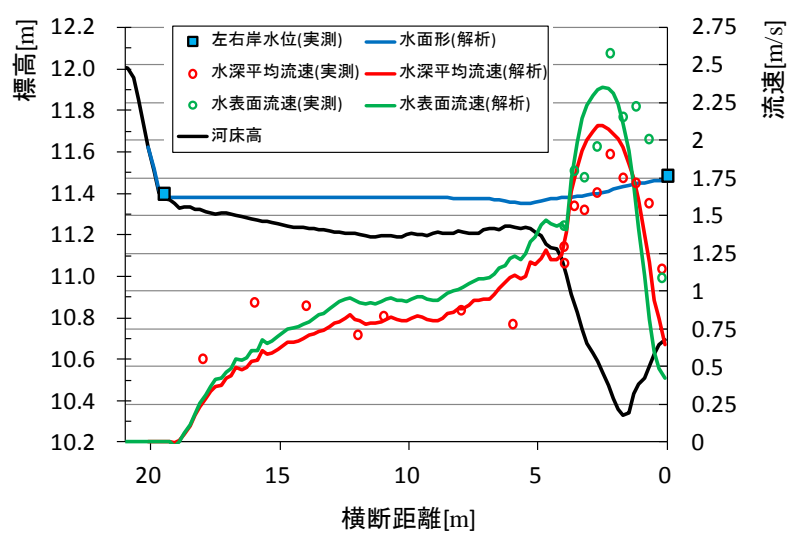

図-10 水表面 - 水深平均流速, 左右岸水位 (断面e)

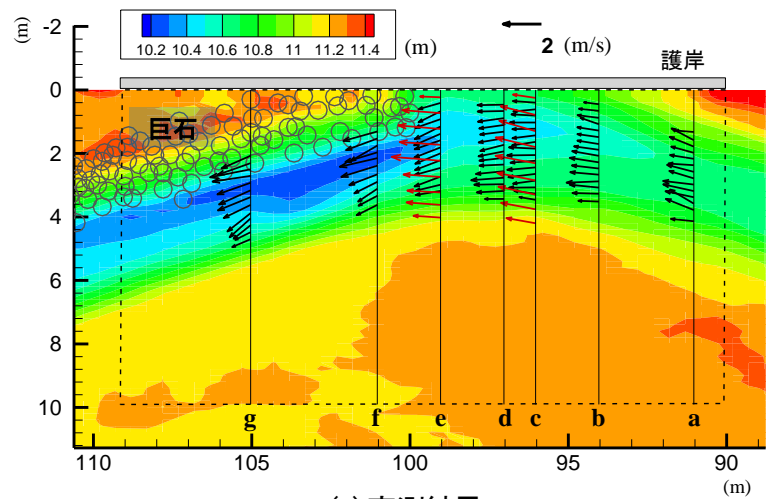

(a) 実測結果

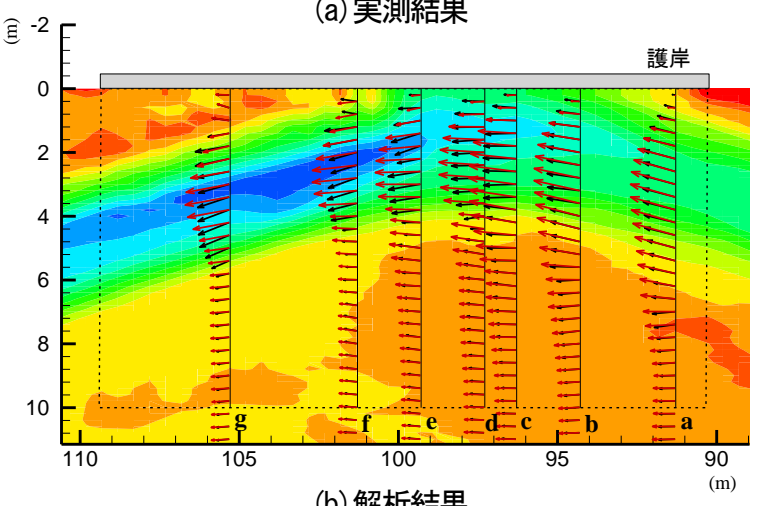

図-11 水表面(赤) · 底面 (黒) 流速

水敷から低水路一向かう流れと, 右岸の護岸付近でもぐ り込み低水路内岸へと向から流れがぶつかるためと考え られる. このように，上下流の広い範囲で観測された水 位や河床形状に加え, 本観測法より計測された水衝部周 辺の詳細な流速分布と地形データを利用し，流れ場全体 を説明するように本解析法を適用することは, 計測結果 を補完し，水衝部流れの現象理解に有効であると言える. 

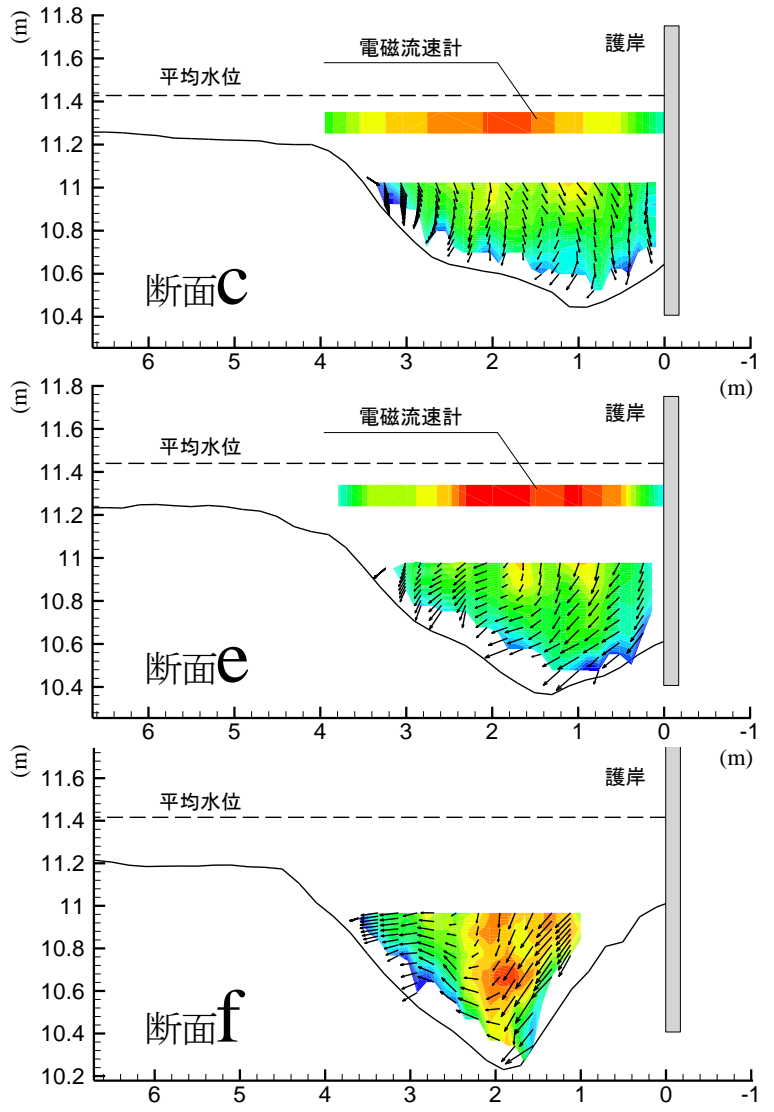

(a) 実測結果

\section{5. 結論}

本研究では，ADCPの流速計測ビームを用いた三次元 流れと河床形状の高精度観測法を開発し，浅水流場の仮 定を用いない底面流速解析法を2011年常願寺川現地実験 へ適用し堤防護岸際の局所流場への適用性を検証した。 その結果以下の結論を得た。

1. $\mathrm{ADCP} の$ 流速計測ビームを用いる本計測法は，構造 物周辺の河床形状を精度よく計測できることを示した。 また，4本の流速計測ビームを個別に用いて流れと河床 形状を計測する本観測法は，構造物周辺の複雑な流れと 河床形状の観測に有効である.

2. 本解析法は堤防護岸際局所流場における二次流と運 動量交換の特徴を定量的に説明出来る.

3. 構造物周辺における複雑な三次元流れ場と局所洗掘 については，既存の水位縦断観測や横断測量結果に加え て，本観測法と解析法を統合的に用いることによって解 明に向かっていると判断される.

\section{参考文献}

1) 長田健吾，安部友則，福岡捷二 : 急流河川における低水路護 岸沿いの深掘れ流路形成とその特性，河川技術論文集，第13 巻, pp.321-326, 2007.

2) Timothy W. Halting, Pascale M. Biron and Michael F. Lapointe : Predicting equilibrium scour-hole geometry near angled stream
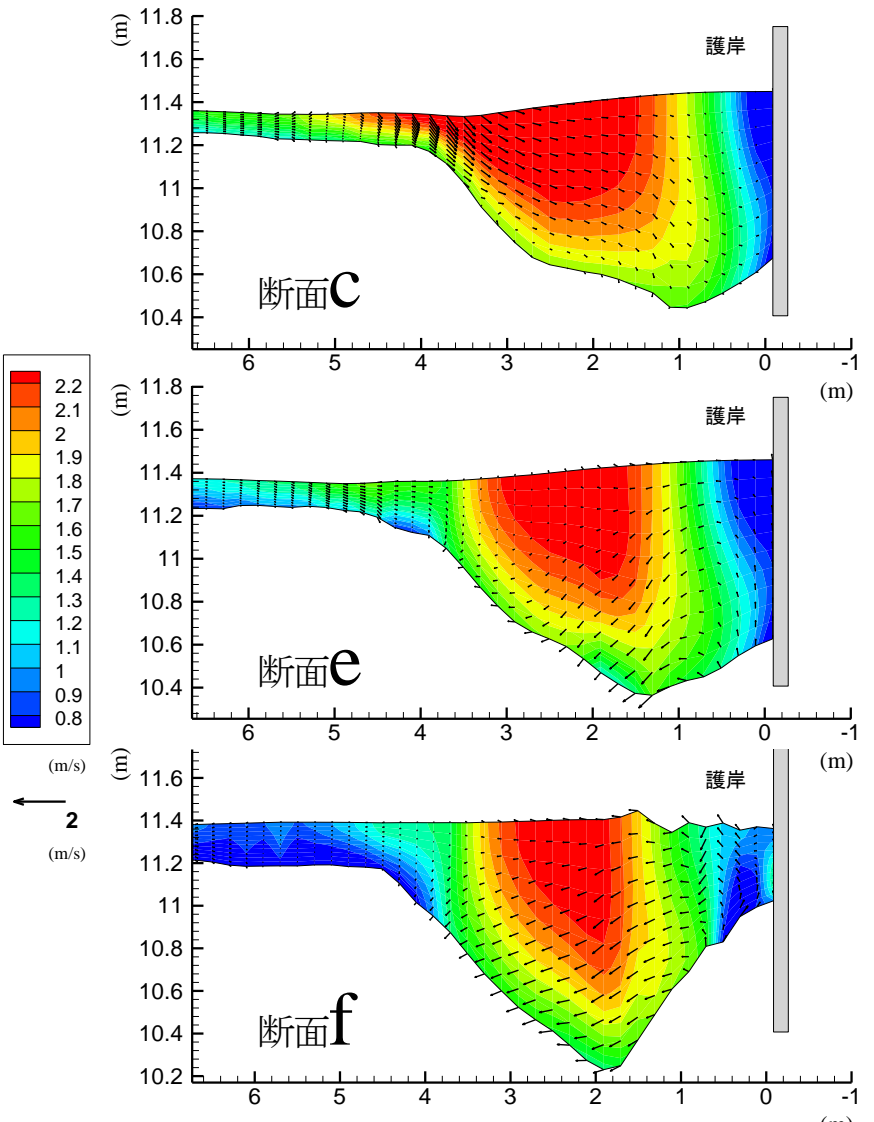

(b) 解析結果

二次流ベクトルの比較

deflectours using a three-dimensional numerical flow model, Journal of Hydraulic Engineering, pp.983-988, August, 2007.

3) Bui Minh Duc and Wolfgang Rodi : Numerical simulation of contraction scour in an open laboratory channel, Journal of Hydraulic Engineering, pp.367-377, April, 2008.

4) 内田龍彦，福岡捷二 : 浅水流の仮定を用いない水深積分モデ ルによる底面流速の解析法，水工学論文集，第56巻, pp. 1225-1230, 2012.

5) 輿石大，内田龍彦，長谷川賢市，内藤ゆう子，福岡捷二： ADCPを用いた局所流計測法の開発と堤防際の水衝部流れ の適用，河川技術論文集，第18巻，pp.239-244，2012.

6) 二瓶泰雄, 色川有, 井出恭平, 高村智之 : 超音波ドップラー 流速分布計を用いた河川流量計測法に関する検討，土木学会 論文集B，vol.64，No.2，pp.99-114， 2008.

7) Gunawan, B., Sterling, M., Tang, X., Knight, D. W. : Measuring and modelling flow structures in a small river, River Flow, pp.179-186, 2010.

8) Teledyne RD Instruments : Acoustic Doppler Current Profiler Principles of Operation A Practical Primer, December, 2006.

9) 小池田真介, 石井陽, 岩井久, 石川俊之, 福岡捷二: 水衝部 対策を施工した砂州による自然性の高い河岸防護工の創出, 河川技術論文集，第18巻，pp.233-238，2012.

10) David S. Muller, Jorge D. Abad, Carlos M. Garcia, Jeffery W. Gartner, Marcelo H. Garcia and Kevin A. Oberg : Errors in acoustic Doppler profiler velocity measurements caused by flow disturbance, Journal of Hydraulic Engineering, pp.1411-1420, December, 2007.

11) 輿石大, 内田龍彦, 福岡捷二 : 水表面流速方程式を付加し た底面流速解析法の開発と河川合流部への適用，水工学論 文集，第56巻，pp. 835-840， 2012.

12)福岡捷二 : 洪水流の水理と河道の設計法, 森北出版, 2005. 